\title{
37. CHEMICAL ANALYSES AND MINOR ELEMENT COMPOSITION OF LEG 29 BASALTS
}

\author{
A. T. Ovenshine, Gary R. Winkler, U. S. Geological Survey, Menlo Park, California \\ Peter B. Andrews, New Zealand Geological Survey, Christchurch, New Zealand \\ and \\ Victor A. Gostin, University of Adelaide, Adelaide, South Australia
}

\begin{abstract}
Drilling on Leg 29 recovered basalts at five sites. Three of the basalts were from pillow flows, one from a massive lava flow, and one from an intrusion. No major differences between the rocks from the five sites are found in major oxide, normative mineralogical, and minor element composition. However, there are minor differences of unknown significance between the sites close to New Zealand and the sites close to Australia. Chemically, the Leg 29 basalts are intermediate in composition between oceanic tholeiites and oceanic alkalic basalts.
\end{abstract}

\section{INTRODUCTION}

Basalt basement was reached and penetrated at Sites 278, 279 (Hole 279A), 280 (Hole 280A), 282, and 283. The purpose of this paper is to provide abbreviated descriptions of the basalts based mainly on shipboard examination of cores and thin sections and to present major oxide chemical analyses, minor element compositions, and CIPW norms.

\section{LITHOLOGY OF LEG 29 BASALTS}

Tables 1,2, and 3 contain analytical data and normative compositions of basalts recovered from the five sites. In the following general descriptions of the basalt cores, the focus is upon the major megascopic properties of the rocks as they would be viewed by field geologists. Detailed studies by specialists are included elsewhere in this volume.

\section{Site 278}

Drilling at Site 278 penetrated the upper portion of a pillow flow, although the precise upper contact was not recovered. Cores recovered from several complete or nearly complete pillows suggest that they are up to 20 $\mathrm{cm}$ thick with black glass rinds as much as $3 \mathrm{~cm}$ thick. The outer surface of the rind is frequently composed of orange palagonite. Inferred interpillow material is principally micritic limestone (Figure 1) containing fragments of glass, basalt, and palagonite. Tests of partially recrystallized foraminifera can be recognized in thin sections of the interpillow limestone which was probably developed from a foraminiferal-nannofossil ooze.

In hand specimen the fresh rock is olive-black (5Y2/1) porphyritic basalt, with phenocrysts of plagioclase comprising from $5 \%$ to $15 \%$ of the volume. Rare, white calcite-filled amygdules averaging $0.5 \mathrm{~mm}$ in diameter occur preferentially in, and just beneath, the glassy pillow rims. In thin section the basalts consist of labradorite, altered acicular pyroxene, iddingsite(?) developed after olivine, and abundant veinlets of sparry calcite, chalcedony, and micritic limestone. Unaltered olivine euhedra occur in the fresh glass of the pillow rims.

\section{Site 279 (Hole 279A)}

Basement recovery at Hole 279A consisted of three core sections of fine-grained dark gray basalts interpreted as the upper few meters of a massive flow. The basalts of Core 12, Section 1 are vesicular to amygdaloidal, subaphanitic to very fine-grained plagioclaseporphyritic basalts, that grade to nonvesicular and nonporphyritic fine-grained basalts toward the base of the core. The basalts of Core 13, Section 1, and Core 13, Section 2 are in lithic continuity with the vesicular basalts of Core 12, Section 1, but differ from them in their slightly coarser grain size and lack of vesicles and phenocrysts. The nonvesicular basalts are subfriable, and during drilling many of the short core segments were abraded to barrel shapes.

In the upper $30 \mathrm{~cm}$ of Core 12 , Section 1 , vesicles and amygdules comprise up to $40 \%$ of the rock volume. The vesicles range from 0.5 to $4 \mathrm{~mm}$ in diameter, averaging $1.5 \mathrm{~mm}$. Approximately $50 \%$ of the vesicles are unfilled. The remaining $50 \%$ are partly to completely filled with white calcite, chlorite, or a gray-blue zeolite(?). Pyrite subhedra occur sparingly in some of the vesicles.

In hand specimen the basalts of Core 12, Section 1 have a color index of 70 , and consist of $1 \%$ white plagioclase phenocrysts ranging to $4 \mathrm{~mm}$ in length, in a subaphanatic to very fine-grained groundmass that consists of equal parts of feldspar laths and pyroxene plus glass(?). In thin section the basalts of Core 13, Section 2 have an intersertal texture and consist of $0.2-0.4 \mathrm{~mm}$ labradorite laths (35\%), anhedral pyroxene $(30 \%)$, patches of partially altered crystallite-rich brown glass 
TABLE 1

Major Oxide Analyses of Leg 29 Basalts

\begin{tabular}{|c|c|c|c|c|c|c|c|c|c|c|}
\hline & \multicolumn{9}{|c|}{ Lab. No. } & \multirow[b]{3}{*}{ Average } \\
\hline & $\begin{array}{l}\text { M119 } \\
549 \mathrm{~W}\end{array}$ & $\begin{array}{l}\text { M119 } \\
950 W\end{array}$ & $\begin{array}{l}\text { M119 } \\
951 W\end{array}$ & $\begin{array}{l}\text { M119 } \\
952 W\end{array}$ & $\begin{array}{l}\text { M119 } \\
953 W\end{array}$ & $\begin{array}{c}\text { M119 } \\
\text { 954Wa }\end{array}$ & $\begin{array}{l}\text { M119 } \\
955 \mathrm{~W}\end{array}$ & $\begin{array}{l}\text { M119 } \\
956 \mathrm{~W}\end{array}$ & $\begin{array}{l}\text { M119 } \\
957 \mathrm{~W}\end{array}$ & \\
\hline & $\begin{array}{c}\text { Sample } \\
278- \\
35-3\end{array}$ & $\begin{array}{l}\text { Sample } \\
278- \\
35, \text { CC }\end{array}$ & $\begin{array}{c}\text { Sample } \\
279 A^{-} \\
12-1\end{array}$ & $\begin{array}{l}\text { Sample } \\
279 \mathrm{~A}- \\
13-2\end{array}$ & $\begin{array}{l}\text { Sample } \\
280 \mathrm{~A}- \\
23-4\end{array}$ & $\begin{array}{c}\text { Sample } \\
282- \\
18-2\end{array}$ & $\begin{array}{c}\text { Sample } \\
282- \\
18-3^{\mathrm{a}}\end{array}$ & $\begin{array}{c}\text { Sample } \\
283- \\
18-1\end{array}$ & $\begin{array}{c}\text { Sample } \\
283- \\
19-1\end{array}$ & \\
\hline $\mathrm{SiO}_{2}$ & 48.1 & 48.3 & 48.1 & 48.9 & 46.7 & 46.6 & 35.6 & 46.3 & 45.7 & 47.3 \\
\hline $\mathrm{Al}_{2} \mathrm{O}_{3}$ & 16.8 & 17.2 & 15.1 & 15.0 & 17.3 & 17.8 & 13.5 & 16.1 & 15.8 & 16.4 \\
\hline $\mathrm{Fe}_{2} \mathrm{O}_{3}$ & 3.8 & 3.9 & 2.7 & 3.3 & 3.2 & 5.6 & 5.1 & 7.5 & 5.6 & 4.4 \\
\hline $\mathrm{FeO}$ & 3.8 & 3.6 & 5.9 & 6.3 & 6.2 & 2.7 & 2.8 & 3.7 & 3.4 & 4.4 \\
\hline $\mathrm{MgO}$ & 6.4 & 6.4 & 6.0 & 7.0 & 6.3 & 2.7 & 3.8 & 6.8 & 7.8 & 6.2 \\
\hline $\mathrm{CaO}$ & 14.1 & 14.4 & 13.2 & 10.6 & 10.6 & 12.1 & 19.9 & 6.3 & 5.7 & 10.9 \\
\hline $\mathrm{Na}_{2} \mathrm{O}$ & 2.0 & 2.2 & 2.6 & 2.3 & 2.6 & 3.1 & 3.2 & 3.5 & 3.5 & 2.7 \\
\hline $\mathrm{K}_{2} \mathrm{O}$ & 0.29 & 0.25 & 0.22 & 0.20 & 0.07 & 0.63 & 0.63 & 0.68 & 0.52 & 0.36 \\
\hline $\mathrm{H}_{2} \mathrm{O}+$ & 1.3 & 1.2 & 0.60 & 1.5 & 1.7 & 1.3 & 1.6 & 2.8 & 3.1 & 1.7 \\
\hline $\mathrm{H}_{2} \mathrm{O}-$ & 1.7 & 1.6 & 1.2 & 1.8 & 1.9 & 2.0 & 2.4 & 5.1 & 5.9 & 2.7 \\
\hline $\mathrm{TiO}_{2}$ & 0.91 & 0.88 & 1.3 & 1.4 & 0.91 & 1.6 & 1.2 & 1.8 & 1.8 & 1.32 \\
\hline $\mathrm{P}_{2} \mathrm{O}_{5}$ & 0.10 & 0.10 & 0.19 & 0.18 & 0.07 & 0.24 & 0.19 & 0.22 & 0.26 & 0.17 \\
\hline $\mathrm{MnO}$ & 0.11 & 0.11 & 0.16 & 0.12 & 0.17 & 0.17 & 0.23 & 0.18 & 0.14 & 0.14 \\
\hline $\mathrm{CO}_{2}$ & 0.59 & 0.52 & 1.6 & 0.03 & 1.6 & 2.5 & 11.2 & 0.08 & 0.09 & 0.88 \\
\hline Total & 100 & 101 & 99 & 99 & 99 & 99 & 101 & 101 & 99 & 99.57 \\
\hline
\end{tabular}

Note: Analytical methods described in USGS Prof. Paper 575-B, p. 187-191. Analyst: Hirbert Kirshenbaum.

${ }^{\mathrm{a}}$ Not used in computing average.

TABLE 2

CIPW Weight Norms of Leg 29 Basalts

\begin{tabular}{|c|c|c|c|c|c|c|c|c|c|}
\hline & \multicolumn{9}{|c|}{ Sample } \\
\hline & $278-35-3$ & $278-35, \mathrm{CC}$ & $279 A-12-1$ & 279A-13-2 & $280 \mathrm{~A}-23-4$ & $282-18-2$ & $282-18-3$ & $283-18-1$ & 283-19-1 \\
\hline Quartz & 2.8 & 1.6 & 2.2 & 3.8 & 1.8 & 6.0 & & 1.3 & 0.6 \\
\hline Orthoclase & 1.7 & 1.5 & 1.3 & 1.2 & 0.4 & 3.8 & 3.8 & 4.2 & 3.3 \\
\hline Albite & 17.2 & 18.8 & 22.5 & 20.1 & 22.6 & 27.0 & 27.4 & 30.9 & 31.7 \\
\hline Anorthite & 36.6 & 36.7 & 29.6 & 31.0 & 36.2 & 33.8 & 20.8 & 27.3 & 27.7 \\
\hline Wollastonite & 12.6 & 13.1 & 10.8 & 9.1 & 2.9 & 4.2 & 2.6 & 1.3 & 0.1 \\
\hline Enstatite & 16.2 & 16.1 & 15.3 & 18.0 & 16.1 & 6.9 & 5.2 & 17.6 & 20.8 \\
\hline Ferrosilite & 2.6 & 2.2 & 6.9 & 7.0 & 7.8 & & & & \\
\hline Forsterite & & & & & & & 3.1 & & \\
\hline Magnetite & 5.6 & 5.7 & 4.0 & 4.9 & 4.8 & 4.8 & 6.4 & 7.6 & 6.6 \\
\hline Hematite & & & & & & 2.5 & 0.8 & 2.6 & 1.4 \\
\hline Ilmenite & 1.8 & 1.7 & 2.5 & 2.7 & 1.8 & 3.1 & 2.3 & 3.6 & 3.7 \\
\hline Apatite & 0.2 & 0.2 & 0.5 & 0.4 & 0.2 & 0.6 & 0.5 & 0.5 & 0.7 \\
\hline Calcite & 1.4 & 1.2 & 3.7 & 0.1 & 3.7 & 5.9 & 25.7 & 0.2 & 0.2 \\
\hline Total & 98.7 & 98.8 & 99.3 & 98.3 & 98.3 & 98.6 & 98.6 & 97.1 & 96.8 \\
\hline Salic & 58.4 & 58.6 & 55.6 & 56.1 & 61.1 & 70.6 & 52.0 & 63.6 & 63.3 \\
\hline Femic & 40.3 & 40.3 & 43.7 & 42.2 & 37.2 & 28.0 & 46.6 & 33.5 & 33.5 \\
\hline
\end{tabular}



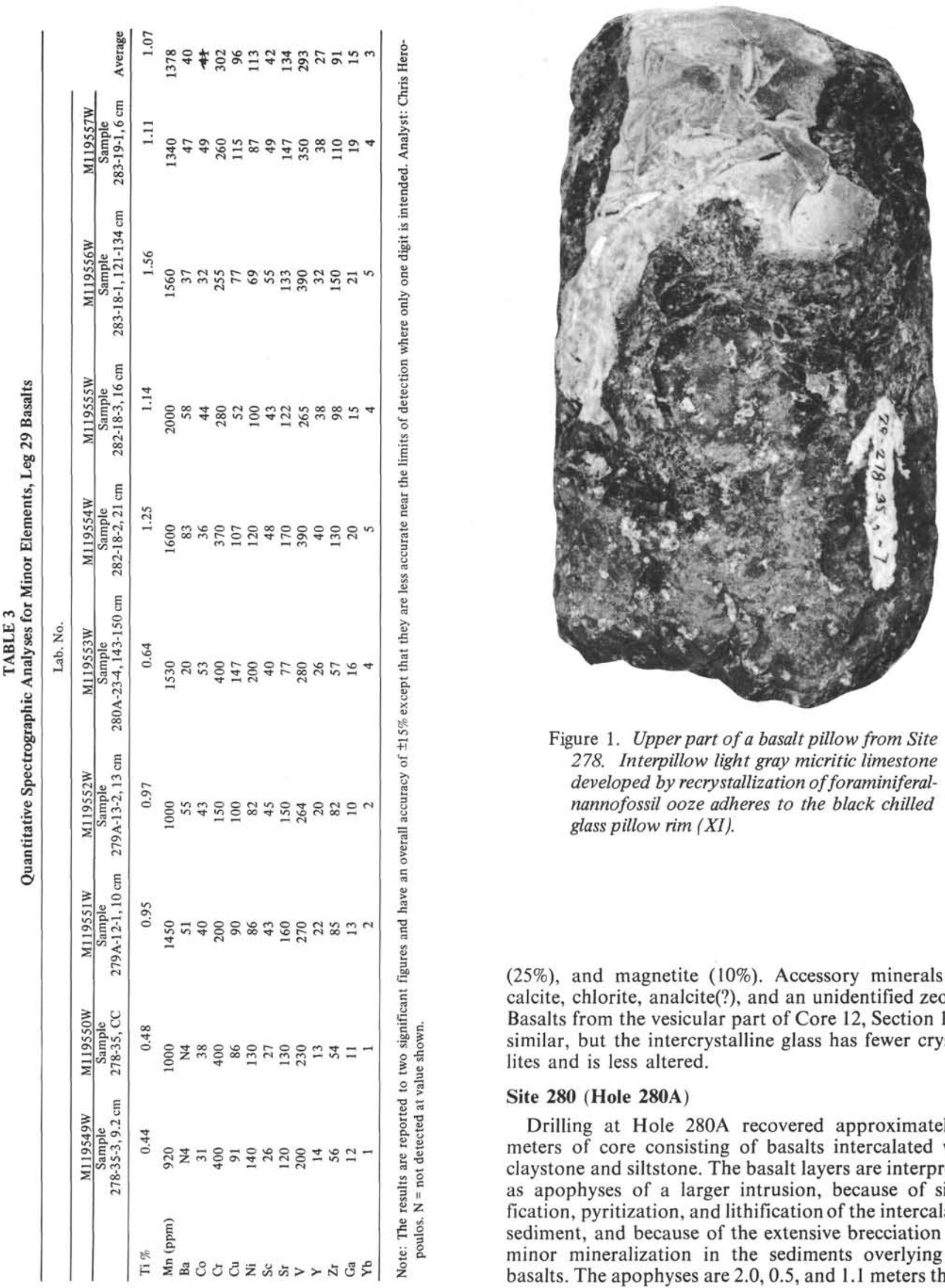

Figure 1. Upper part of a basalt pillow from Site 278. Interpillow light gray micritic limestone developed by recrystallization of foraminiferalnannofossil ooze adheres to the black chilled glass pillow rim $(X I)$.

(25\%), and magnetite (10\%). Accessory minerals are calcite, chlorite, analcite(?), and an unidentified zeolite. Basalts from the vesicular part of Core 12, Section 1 are similar, but the intercrystalline glass has fewer crystallites and is less altered.

\section{Site 280 (Hole 280A)}

Drilling at Hole $280 \mathrm{~A}$ recovered approximately 5 meters of core consisting of basalts intercalated with claystone and siltstone. The basalt layers are interpreted as apophyses of a larger intrusion, because of silicification, pyritization, and lithification of the intercalated sediment, and because of the extensive brecciation and minor mineralization in the sediments overlying the basalts. The apophyses are 2.0,0.5, and 1.1 meters thick. 
The rock is greenish-black, holocrystalline, subophitic, fine-grained, pyroxene-labradorite basalts containing magnetite in amounts ranging from $2 \%$ to $10 \%$ by volume. Recognizable olivine phenocrysts are confined to the lowermost apophysis. The rock is extensively altered to serpentine group minerals, and locally contains minor amounts of pyrite. The most altered portions of the core expand and disintegrate on wetting.

\section{Site $\mathbf{2 8 2}$}

Drilling penetration of basement at Site 282 resulted in recovery of 7.6 meters of core interpreted as altered pillow basalt, or possibly altered broken pillow breccia and aquagene tuff. Veins of calcite, chlorite, limonite, and steatite(?) up to several centimeters in width, pervade the highly fractured core. Radially oriented calcite fractures are common in recognizable pillow segments, but are generally confined to the greenish-black, partially devitrified glass rims. In some instances, calcite, accompanied by minor pyrite, appears to have completely replaced basalts (Sample 29-282-18-2, 53-60 cm).

In hand specimen the basalts are greenish-gray ( $5 \mathrm{GY}$ $7 / 2$ ), ranging to bluish-gray and light bluish-gray. Locally, plagioclase and pyroxene crystals can be recognized under the hand lens, but generally individual crystals are indistinguishable. Thin sections of the rare, unaltered patches of basalts show subophitic intergrowths of zoned plagioclase and magnetite-rich pyroxene in a devitrified groundmass. Most of the rock is pervasively altered to calcite, brown iron oxide, and serpentine group minerals.

Minute grains of native copper were recognized on slabbed core surfaces, but quantitative spectrographic analysis for copper (Table 3) did not show unusually high values in comparison to the other Leg 29 basalts.

\section{Site $\mathbf{2 8 3}$}

Drilling at Site 283 encountered basalts that were originally either pillow lava or broken pillow breccia. This interpretation is not straightforward, however, because a color change in the overlying sediments could indicate weak metamorphism by an intrusion. The interpretation as a pillow flow or broken pillow breccia is based on: (1) abundant devitrified glass in the upper part of the core, (2) occurrences of breccia containing both glass and basalts, (3) amygdules occurring throughout the core, and (4) one core segment (283-19$1,6 \mathrm{~cm}$ ) containing the upper half of a pillow with a glass patina and chilled rim, grading downwards to holocrystalline basalts.

The upper $20 \mathrm{~cm}$ of the core consists of light greenishgray devitrified volcanic glass with abundant veinlets of calcite and serpentine and one tabular mass of dark red palagonite that is probably altered interpillow glass. The rock consists of rare altered feldspar laths $(2 \%)$ in an altered groundmass consisting of clay minerals, zeolite, and serpentine.

The remaining 1.3 meters of core consists of dark greenish-gray amygdaloidal basalts $(80 \%)$, calcite veins $(15 \%)$, and dark fragments of serpentinized glass (5\%). In several places the rock exhibits autoclastic, or tectonic breccia textures. In thin section the original texture of the fine-grained rock, which may have been intersertal and subophitic, is largely obscured by the radial habit of the alteration products. Altered plagioclase laths comprise $20 \%$, black opaque minerals $(10 \%)$, partially altered olivine and pyroxene (30\%), serpentine(?) after glass $(10 \%)$, calcite $(5 \%)$, with the remainder consisting of clay minerals, serpentine, and zeolite.

\section{CLASSIFICATION}

Comparison of major oxide, normative mineralogical, and minor element compositions (Tables 1,2, and 3) does not indicate major differences between the basalts from the five sites. Minor differences of unknown significance, however, do exist between the basalts from the sites near New Zealand (278 and 279) and the basalts from sites near Australia (280, 282, and 283). The "New Zealand" basalts show, in major oxide composition, lower $\mathrm{Na}_{2} \mathrm{O}$ and $\mathrm{K}_{2} \mathrm{O}$ values than the "Australian" basalts (Table 1). Similarly, contents of $\mathrm{Zr}, \mathrm{Ga}$, and $\mathrm{Yb}$ are lower in the New Zealand basalts than in the Australian ones.

The problems in classifying the Leg 29 basalts occur because their composition tends to be close to various proposed chemical boundaries. For example, on the AFM diagram commonly used to separate subalkaline from alkaline and calcalkaline basalts (Figure 2), the Leg 29 basalts straddle the boundary of Irvine and Baragar (1971, p. 528). Somewhat improved discrimination is offered by the plot of weight percent alkalies against silica (Figure 3). This plot has also been used to discriminate alkaline and tholeiitic rocks of Hawaii (MacDonald and Katsura, 1964, p. 87) and Japan, Korea, and Manchuria (Kuno, 1968, p. 627). Considered as a group, the Leg 29 basalts straddle the highalumina versus alkali-olivine field boundary. This was also true for many samples from DSDP Legs 15 and 17 (Bence et al., 1973, p. 997 and 1000).

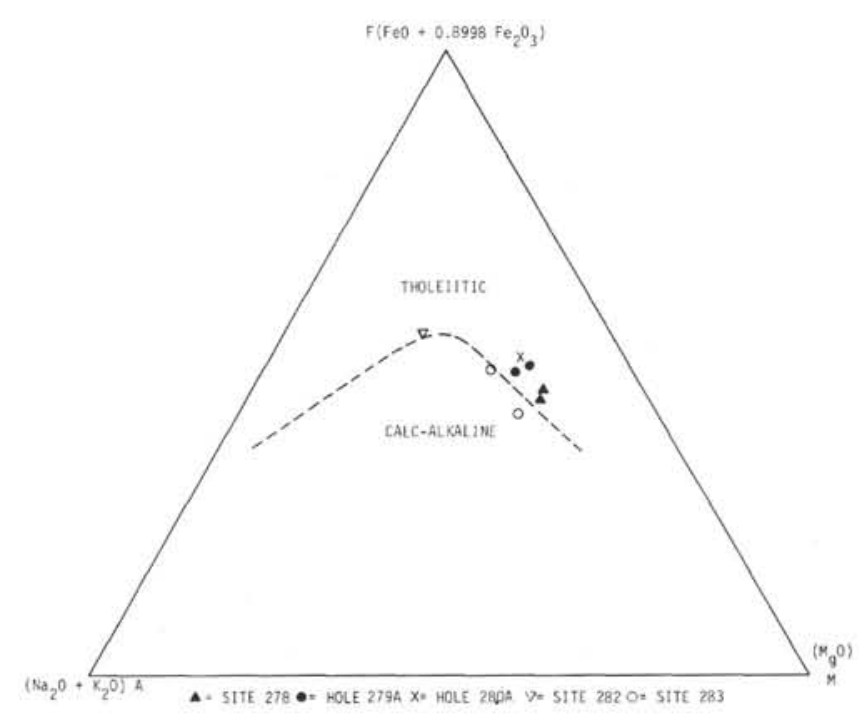

Figure 2. AFM diagram, Leg 29 basalts (after Irvine and Baragar, 1971, p. 528). 


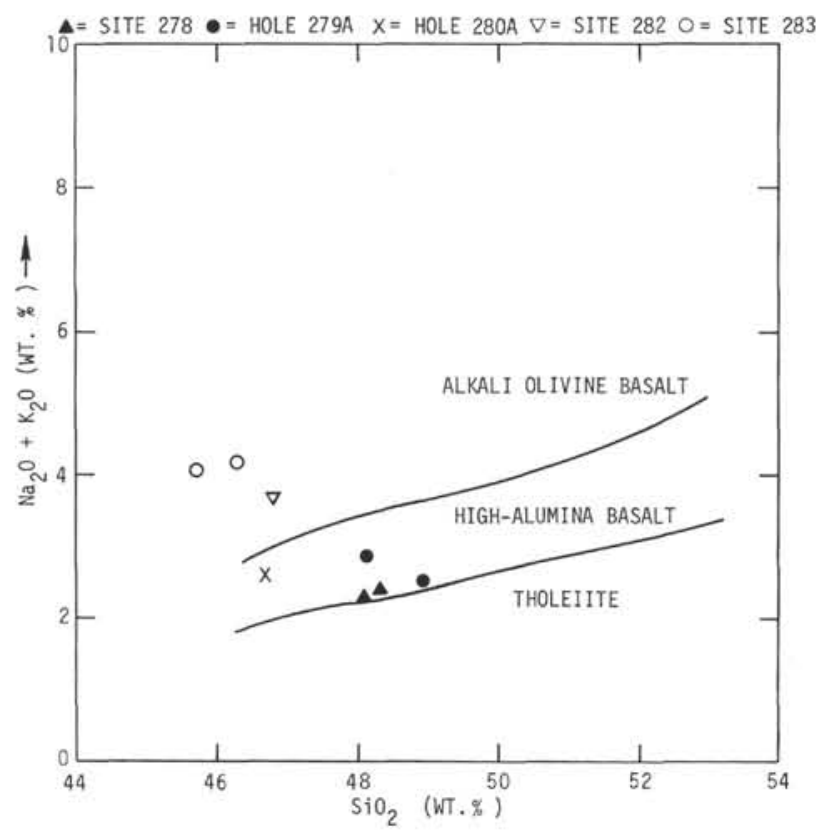

Figure 3. Alkali-silica variation diagram, Leg 29 basalts (after Kuno, 1968, p. 627).

Often considerable emphasis in classification is placed on differences in alumina content between calcalkaline and tholeiitic basalts. Generally, calcalkaline basalts $283 \mathrm{Y}$. The "New Zealand" basalts show, in major oxide contain $17 \%-20 \% \mathrm{Al}_{2} \mathrm{O}_{3}$, whereas tholeiitic basalts contain $12 \%-17 \%$. The contrast should be especially prominent on a plot of $\mathrm{Al}_{2} \mathrm{O}_{3}$ against normative plagioclase composition (Figure 4). Considered as a group, the Leg 29 rocks straddle the field boundary, as do abyssal basalts from the Mid-Atlantic Ridge (Irvine and Baragar, 1971, p. 536).

A summary of the results obtained by classifying the Leg 29 basalts according to the schemes shown in Figures 2, 3, and 4 is presented in Table 4. Table 5 may give the best appreciation of the intermediate character of the rocks. Clearly, the Leg 29 basalts have chemical aspects of both oceanic tholeiites and oceanic alkaline basalts, reported by Engel et al. (1965, table 5).

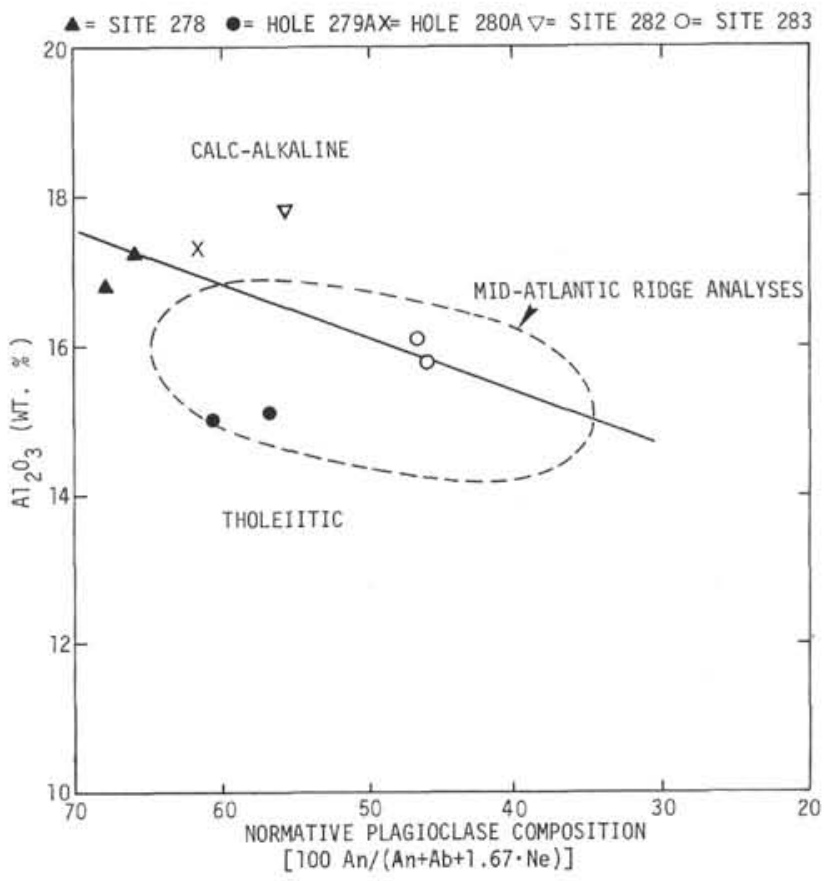

Figure 4. Alumina versus normative plagioclase composition, Leg 29 basalts (after Irvine and Baragar, 1971, p. 536).

\section{REFERENCES}

Bence, A. E., Papike, J. J., Chandrasekharam, D., and Cameron, M., 1973. Petrology of basalts from Leg 15 of the Deep Sea Drilling Project; the central Caribbean, and Petrology of basalts from Leg 17 of the Deep Sea Drilling Project; central Pacific Basin: Am. Geophys. Union Trans., v. 54 , no. 11 , p. $995-1001$.

Engel, A. E. J., Engel, G. G., and Havens, R. C., 1965. Chemical characteristics of oceanic basalts and the upper mantle: Geol. Soc. Am. Bull., v. 76, p. 719-734.

Irvine, T. N. and Baragar, W. R. A., 1971. A guide to the chemical classification of the common volcanic rocks: Canadian J. Earth Sci., v. 8, p. 523-548.

Kuno, H., 1968. Differentiation of basalt magmas. In Hess, H. H. and Poldervaart, A. (Eds.), Basalts: New York (Interscience), p. 623-688.

MacDonald, G. A. and Katsura, T., 1964. Chemical composition of Hawaiian lavas: J. Petrol., v. 5, p. 82-133.

TABLE 4

Classification of Leg 29 Basalts

\begin{tabular}{|c|c|c|c|}
\hline \multicolumn{4}{|c|}{ Classification Method } \\
\hline Hole & AFM (Figure 2) & $\begin{array}{l}\text { Alkali-Silica Varia- } \\
\text { tion Diagram (Figure 3) }\end{array}$ & $\begin{array}{l}\mathrm{A}_{1}{ }_{2} \mathrm{O}_{3} \text { vs. Normative Plagio- } \\
\text { clase Composition (Figure 4) }\end{array}$ \\
\hline 278 & Tholeiitic basalt & High-alumina basalt & Tholeiitic basalt ${ }^{a}$ \\
\hline $279 \mathrm{~A}$ & Tholeiitic basalt & High-alumina basalt & Tholeiitic basalt \\
\hline $280 \mathrm{~A}$ & Tholeiitic basalt & High-alumina basalt & Calcalkaline basalt \\
\hline 282 & Tholeiitic basalt & Alkali olivine basalt & Calcalkaline basalt \\
\hline 283 & Calcalkaline basalt & Alkali olivine basalt & Calcalkaline basal $\mathrm{t}^{\mathrm{a}}$ \\
\hline
\end{tabular}

${ }^{a}$ One of the two analyses plots on the field boundary. 
TABLE 5

Comparative Chemical Compositions of Oceanic Basalts

\begin{tabular}{|c|c|c|c|}
\hline $\begin{array}{c}\text { Weight } \\
(\%)\end{array}$ & $\begin{array}{l}\text { Oceanic }^{a} \\
\text { Tholeiite }\end{array}$ & $\begin{array}{c}\text { Leg } 29^{\mathrm{b}} \\
\text { Basalt }\end{array}$ & $\begin{array}{c}\text { Oceanic }^{c} \\
\text { Alkalic } \\
\text { Basalt }\end{array}$ \\
\hline $\mathrm{SiO}_{2}$ & 49.94 & 47.3 & 47.41 \\
\hline $\mathrm{Al}_{2} \mathrm{O}_{3}$ & 16.69 & 16.4 & 18.02 \\
\hline $\mathrm{Fe}_{2} \mathrm{O}_{3}$ & 22.01 & 4.4 & 4.17 \\
\hline $\mathrm{FeO}$ & 6.90 & 4.4 & 5.80 \\
\hline $\mathrm{MgO}$ & 7.28 & 6.2 & 4.79 \\
\hline $\mathrm{CaO}$ & 11.86 & 10.9 & 8.65 \\
\hline $\mathrm{Na}_{2} \mathrm{O}$ & 2.76 & 2.7 & 3.99 \\
\hline $\mathrm{K}_{2} \mathrm{O}$ & 0.16 & 0.36 & 1.66 \\
\hline $\mathrm{H}_{2} \mathrm{O}+$ & & 1.7 & \\
\hline $\mathrm{H}_{2} \mathrm{O}-$ & - & 2.7 & 2.45 \\
\hline $\mathrm{TiO}_{2}$ & 1.51 & 1.32 & 2.87 \\
\hline $\mathrm{P}_{2} \mathrm{O}_{5}$ & 0.16 & 0.17 & 0.92 \\
\hline $\mathrm{MnO}$ & - & 0.14 & - \\
\hline $\mathrm{CO}_{2}$ & - & 0.88 & - \\
\hline Sum & 99.17 & 99.57 & 100.73 \\
\hline \multicolumn{4}{|l|}{ ppm } \\
\hline Mn & - & 1378 & - \\
\hline $\mathrm{Ba}$ & 14 & 40 & 498 \\
\hline $\mathrm{Co}$ & 32 & 41 & 25 \\
\hline $\mathrm{Cr}$ & 297 & 302 & 67 \\
\hline $\mathrm{Cu}$ & 77 & 96 & 36 \\
\hline $\mathrm{Ni}$ & 97 & 113 & 51 \\
\hline Sc & 130 & 42 & 815 \\
\hline $\mathrm{Sr}$ & 130 & 134 & 815 \\
\hline V & 292 & 293 & 252 \\
\hline Y & 43 & 27 & 54 \\
\hline $\mathrm{Zr}$ & 95 & 91 & 333 \\
\hline $\mathrm{Ga}$ & - & 15 & - \\
\hline Yo & - & 3 & - \\
\hline $\mathrm{Li}$ & 9 & - & 11 \\
\hline
\end{tabular}

